\title{
Article
}

\section{Stemwood Volume Estimates for a Mixed Temperate Forest using Satellite LiDAR}

\author{
Jacqueline Rosette ${ }^{* 1}$, Peter North ${ }^{* 2}$ and Juan Suárez ${ }^{* 3}$
}

\begin{abstract}
Data from the Geoscience Laser Altimeter System (GLAS) aboard the Ice Cloud and Land Elevation Satellite (ICESat) were used to explore the potential of satellite LiDAR for the estimation of forest parameters such as vegetation height and stemwood volume. This was carried out for the Forest of Dean, Gloucestershire, UK, a semiancient, highly mixed, temperate forest. Previous research suggests use of Waveform Extent (the difference of alternate model fit Signal Begin and Signal End) and a Terrain Index (maximum minus minimum elevations from a $7 \times 7$ matrix, $10 \mathrm{~m}$ resolution DTM) to provide the most robust estimate of maximum canopy height. These waveform-based maximum vegetation height estimations were used to investigate the potential of satellite LiDAR for the estimation of stemwood volume for the tallest species within each footprint. Relationships were established with predictions of stemwood volume calculated from Forestry Commission yield models. These equations succeeded in explaining $68 \%$ of variance with $88.7 \mathrm{~m}^{3} /$ ha RMSE for coniferous species and $\mathrm{R}^{2}$ of 0.65 with $68.2 \mathrm{~m}^{3} / \mathrm{ha}$ RMSE for broadleaf species. The ability of satellite LiDAR waveforms to account for stemwood volume within mixed composition stands was also investigated. Area under the waveform canopy return, maximum canopy height, dominant canopy height and height of cumulative energy percentiles were considered. The height of the $90^{\text {th }}$ percentile of cumulative energy was found to best represent the weighted stemwood volume of heterogeneous stands producing $\mathrm{R}^{2}$ of $0.57,92.3 \mathrm{~m}^{3} /$ ha RMSE and $\mathrm{R}^{2}$ of $0.59,67.5 \mathrm{~m}^{3} /$ ha RMSE for stands dominated by coniferous and broadleaf species respectively. The results of this local study indicate the potential for similar methods to be applied to regional or national scales.
\end{abstract}

Keywords: ICESat, GLAS, stemwood volume, vegetation height, satellite LiDAR

\section{INTRODUCTION}

The necessity of quantifying and monitoring changes in carbon stock has been recognised in international agreements such as the Kyoto Protocol to the United Nations Framework Convention on Climate Change 1997 (UNFCCC, 2007; FOREST RESEARCH, 2006). Estimating this requires prior knowledge of carbon dispersal and, as an effective carbon sink, understanding distribution of vegetation volume.
Corresponding author: Jacqueline Rosette

${ }^{* 1}$ Swansea University, Climate and Land-Surface Systems Interaction Centre (CLASSIC), Department of Geography, Swansea, SA2 8PP, United Kingdom. ggrosette@swansea.ac.uk

${ }^{* 2}$ Swansea University, Climate and Land-Surface Systems Interaction Centre (CLASSIC), Depart-
For the purposes of forest management, quantifying timber volume is of importance for commercial viability and assessing stand processes such as regeneration. Additionally, height is an important input parameter for yield model estimates (EDWARDS and CHRISTIE, 1981; ForESTRY COMMISSION, 2006).

Earth observation plays a significant role in contributing to the knowledge of vegetation distribution and its biophysical properties. Optical remote sensing has been shown to provide indirect associations using reflectance

ment of Geography, Swansea, SA2 8PP, United Kingdom. p.r.j.north@swansea.ac.uk

${ }^{* 3}$ The Forest Research Agency of the Forestry Commission Great Britain, Northern Research Station, Roslin, Midlothian, EH25 9SY, United Kingdom.

juan.suarez@forestry.gsi.gov.uk 
properties for Normalised Difference Vegetation Index (e.g. Defries and TownSHEND, 1994; Los et al., 1994; SELlers et al., 1994) and Leaf Area Index (e.g. Los et al., 2000; MYNENI et al., 2002) although there are difficulties associated with use of reflectance alone (NORTH, 2002). More direct assessment using the physical properties of vegetation and interactions between canopy structure and photons detected by the sensor have been demonstrated through radiative transfer modelling (NORTH, 1996; Ni-MEISTER et al., 2001; KoTCHENOVA et al., 2003).

Active instruments have been exploited to estimate vegetation height and volume using radar (BALTZER et al., 2003; GAVEAU et al., 2003; TANSEY et al., 2004; BALZTER et al., 2007) and more recently LiDAR (Light Detection and Ranging) systems.

Potential for biophysical parameter estimation at local scales has been shown for discrete return airborne laser scanning (e.g. HYYPPÄ et al., 2001; NÆSSET, 2002; PATENAUDE $e t$ $a l ., 2004$ ) and waveform recording devices (LEFSKY et al., 1999a; LEFSKY et al., 1999b; HARDING et al., 2001; DRAKE et al., 2002; DRAKE et al. 2003). The benefits of combining spectral data/ aerial photography and airborne lidar data have also been shown (e.g. Hill and THOMPSON, 2005; SuÁrEZ et al., 2005). Additionally, NELSON et al. (2004) and NELSON et al. (2006) have shown the potential for USA State-wide documentation of commercially viable volume and total above ground biomass using first return airborne LiDAR profiling. Discussions relating to full waveform, satellite LiDAR systems are provided by BUFTON (1989), GARDNER (1992), HARDING $e t$ al. (1994), BRENNER et al. (2003) and HeSE et al. (2005).

An important limitation of remote sensing estimates is that direct account is only taken of above ground biomass whilst root systems would make a substantial contribution to carbon storage. However, JeNkins et al. (2003) have shown a means to overcome this using USA-wide allometric equations for estimating above ground biomass for broad species classes and have found generalised relationships accounting for vegetation component biomass (root, foliage, stem bark and stemwood). This potential has also been demonstrated by FANG et al. (1998) who have related stem volume density $\left(\mathrm{m}^{3} / \mathrm{ha}\right)$ to stand biomass $(\mathrm{Mg} / \mathrm{ha})$ comprising both above and below ground biomass.

The objectives of this study are therefore to explore the use of ICESat/GLAS data for forest inventory and to develop straightforward, repeatable methods for estimating vegetation height and stemwood volume that can be applied to regional and national scales. In particular, we examine how existing methods for stemwood volume estimation based on yield models compare with estimates derived from satellite LiDAR. We assume a sample of height data is available to calibrate LiDAR height estimates.

\section{METHOD}

Study Site

The Forest of Dean, Gloucestershire, UK (Fig. 1; left) is a semi-ancient, heterogeneous, temperate forest, bordering Wales and extending over an area of approximately 11,000 hectares (ROYAL FOREST OF DEAN, 2006). The Forest is managed by the Forestry Commission of Great Britain a
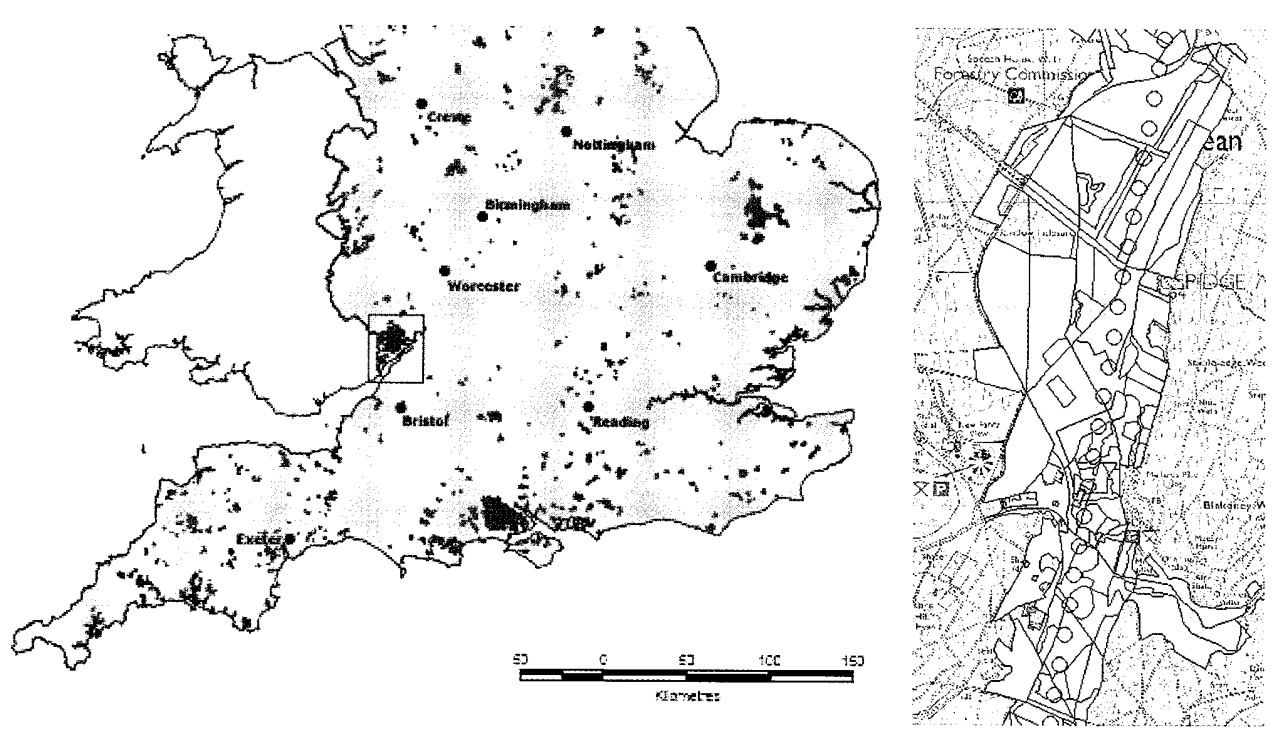

Fig. 1 (left) Map of Forestry Commission Woodland in central and southern England with the Forest of Dean indicated. Source: MAGIC (2007). (right) 1:25,000 scale map of the Forest of Dean overlaid by Forestry Commission sub-compartments and representation of a section of ICESat footprints. North is orientated to the top of the image ( $2 \mathrm{~km} \times 4 \mathrm{~km}$ area shown). Source: ORDNANCE SURVEY (2006) 
division of which, Forest Enterprise, maintains a subcompartment database of management units throughout the area. These sub-compartments (Fig. 1; right) are comprised of discrete, irregularly distributed components with known species, physical conditions and management criteria (Forestry COMMISSION, 2006). Thus for each footprint location, the associated sub-compartment and constituent components permit reference to be made to relevant yield models (EDWARDS and Christie, 1981). This enables prediction of vegetation growth for the given conditions.

The ICESat ground-track crossed the Forest between latitude $51.74^{\circ} \mathrm{N}$ and $51.88^{\circ} \mathrm{N}$ and longitude $2.54^{\circ} \mathrm{W}$ and $2.51^{\circ} \mathrm{W}$. Of the stands sampled by ICESat/GLAS footprints, the most commonly occurring species were Norway Spruce (Picea abies), mixed broadleaf species, Oak (Quercus spp), Corsican Pine (Pinus nigra var maritima), Douglas Fir (Pseudotsuga menziesii), Scots Pine (Pinus sylvestris) and European Larch (Larix decidua). Vegetation was predominantly still in leaf at the time of GLAS data acquisition. Only footprints falling within the contents of the Forestry Commission sub-compartment database were studied and additionally, those footprints which partially traversed urban developments were excluded as surface features would contribute to waveform structure and could not be isolated. This resulted in a total of 69 waveforms analysed.

\section{Yield Models}

Forestry Commission yield models were used to calculate stemwood volume coincident with ICESat footprints. The yield models are empirically-derived and estimate growth over time accounting for habitat conditions and consequently differing growth characteristics between and within species groups. Initial spacing of individuals, species, yield class (defined as an annual increment in $\mathrm{m}^{3} / \mathrm{ha} /$ year) and management (e.g. thinning regime) are used for each model to estimate vegetation parameters which comprise top height, individual tree volume, volume per hectare and mean diameter at breast height by age.

Stemwood volume is defined by EDWARDS and CHRISTIE (1981) as living tree over-bark volume $\left(\mathrm{m}^{3} / \mathrm{ha}\right)$ which, for coniferous species, includes main stem timber of $7 \mathrm{~cm}$ diameter or greater. This was estimated for sub-compartments sampled by each ICESat footprint making reference to the subcompartment database and relevant yield models. Two measures of stemwood volume are used in this study:

\section{Single species stand volume}

The first uses yield model stemwood volume calculated for the tallest species within each footprint, determined from the sub-compartment database. Using one species, identifiable from the waveforms (maximum canopy height estimations), aims to indicate the potential for stemwood volume estimation within pure stands. Footprints were then distinguished accord- ing to whether the tallest species was broadleaf or coniferous to determine whether this would result in an improved correlation with waveform parameters (described in "Waveform estimators of stemwood volume" section).

\section{Mixed stand stemwood volume}

Only six footprints crossing the Forest of Dean sample sub-compartments containing a single species and furthermore several footprints cross more than one sub-compartment. Therefore the second measure represents mixed stands and uses a weighted stemwood volume calculation, taking account of the percentage composition of species within all components of each sub-compartment covered by footprints. Footprints were differentiated according to whether broadleaf or coniferous species formed the greatest percentage cover. Relationships with the waveform parameters discussed above were then calculated.

\section{ICESat/ GLAS Data}

The Ice Cloud and land Elevation Satellite (ICESat) carries the Geoscience Laser Altimeter System (GLAS) and provides near global coverage of between $\pm 86^{\circ}$ latitude. Lasers are operated intermittently, typically three times per annum during February-March, May-June and OctoberNovember. ICESat orbits at an altitude of $600 \mathrm{~km}$ and simultaneously emits $1,064 \mathrm{~nm}$ and $532 \mathrm{~nm}$ wavelength pulses at $40 \mathrm{~Hz}$. This produces a series of elliptical footprints with $64 \mathrm{~m}$ average equivalent circular area diameter and $172 \mathrm{~m}$ intervals between consecutive footprint centres. Further information regarding the mission is discussed by ZwALlY et al. (2002), BRENNER et al. (2003), KICHAK (2003), ABSHIRE et al. (2005), ScHUTz et al. (2005) and NSIDC (2006).

Data from GLAS release V026; level 1A product GLA01 (Global Altimetry data) and level 2 products GLA06 (Global Elevation data) and GLA14 (Global Land Surface Altimetry data) captured on $22^{\text {nd }}$ October 2005 at 8:28am (ZwALLY et al. 2006), were used for this study. These products provide respectively the raw waveform, geographical co-ordinates of footprint locations and a model fit to the waveform using the sum of six Gaussian peaks (Fig. 2b). Near infrared waveforms have been used for the study discussed in this paper. The GLAS Visualizer Tool (10 $0^{\text {th }}$ April 2006 version) was used to explore the waveform, as well as to identify and export relevant parameters.

LiDAR waveforms consist of the returned energy from intercepted surfaces at and above ground level within the area illuminated by the laser pulse. The time for energy from the emitted pulse to be returned to the sensor enables elevations of above-surface features within the footprint to be calculated.

For vegetated areas of significant relief, signals from ground and vegetation elevations may be combined within the returned waveform. This is a particular challenge for broader footprints where the likelihood is increased. Footprints 

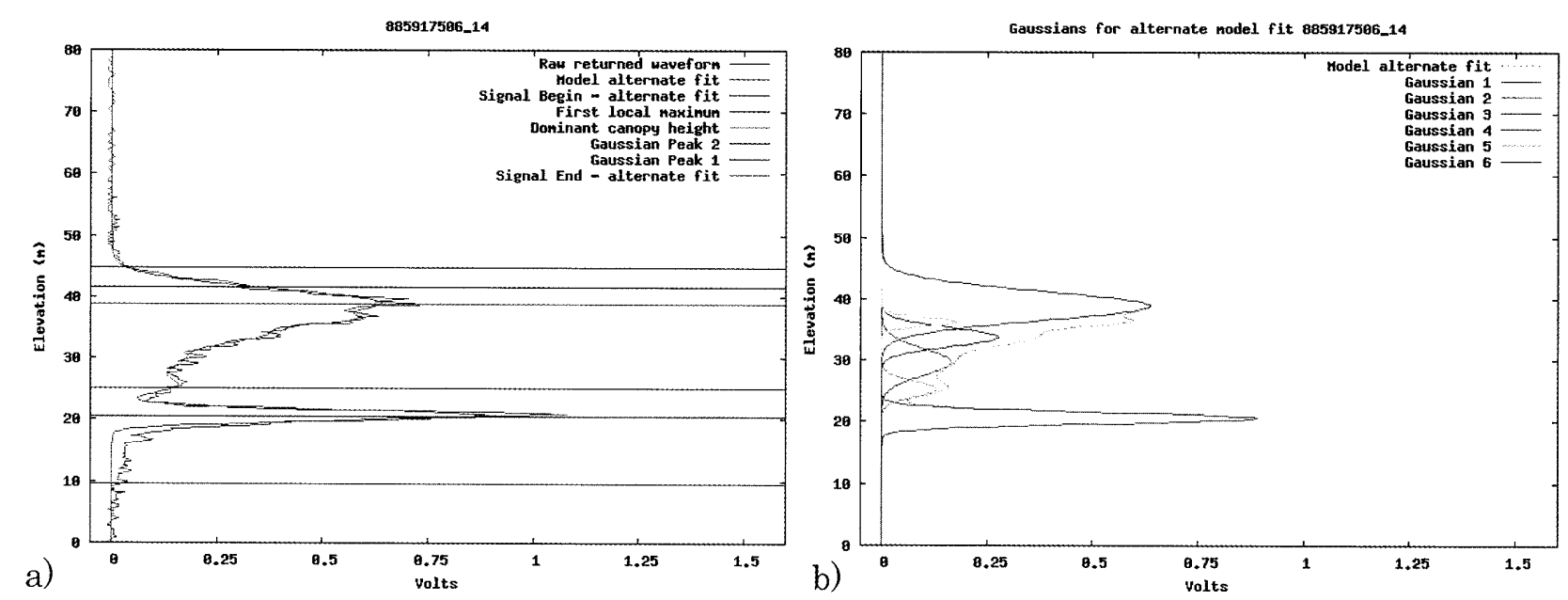

Fig. 2 a) A bimodal waveform typical of vegetated footprints, illustrating key waveform parameters. b) Alternate model fit decomposition; the sum of six Gaussian peaks.

containing vegetation overlying a ground surface of low relief are expected to produce a bimodal LiDAR waveform consisting of a narrow peak pertaining to topography and a broader, more complex return determined by responses from vegetation (Fig. 2). The waveform structure relating to the vegetation return may be considered a function of vegetation volume (surface area of canopy elements) as well as reflectivity at the scattered wavelength.

The work presented in the paper aims firstly to identify an appropriate means of estimating maximum canopy height from satellite LiDAR waveforms. This estimate is then used to identify the region of the waveform attributable to the vegetation. Several methods of estimating stemwood volume from GLAS waveforms are subsequently explored and compared with Forestry Commission yield model predictions.

\section{GLAS Waveform Parameters}

\section{Canopy height}

Key features within waveforms can be identified with the aim of facilitating interpretation (Fig. 2). Signal Begin and Signal End positions are assigned where a background noise threshold is exceeded and represent respectively, the highest canopy surface and lowest ground elevations within the footprint. The distance between these limits is referred to as Waveform Extent (HARDING and CARABAJAL, 2005; LEFSKY et al., 2005).

Adapted from LEFSKY et al. (2005), a Terrain Index for each footprint location was calculated. For the purposes of this study, this consisted of the difference in metres between the highest and lowest elevations within a $7 \times 7$ matrix of a $10 \mathrm{~m}$ resolution DTM (ORDNANCE SuRvey, 2006) about the footprint centre.

Field tree height measurements at nineteen footprint locations were conducted in June 2006. These comprised eight inclinometer measurements of the tree with largest diameter at breast height, one within each $45^{\circ}$ segment of $35 \mathrm{~m}$ radius about the footprint centre.

Removal of the effect of topography from the Waveform Extent is anticipated to provide an estimate of maximum canopy height within a footprint. Waveform Extent and Terrain Index were therefore used to establish a relationship with the greatest of the eight tree height measurements for each footprint.

Previous work (ROSETTE et al. in press) demonstrated significant correlation between waveform estimates of maximum canopy height using Waveform Extent $(W E)$ and Terrain Index $(T I)$ with field measurements $(H)$ taken at footprint locations.

Equation (1) was found to explain $90 \%$ of variance and produced RMSE of $2.86 \mathrm{~m}$ for the Forest of Dean.

$$
H=1.0208^{*} W E-0.7310^{*} T I
$$

Estimated maximum canopy heights resulting from this multiple regression equation are hereafter referred to as $\mathrm{R}_{\text {wт. }}$

HARDING et al. (1998) and NI-MEISTER et al. (2001) note issues associated with allocation of the Signal Begin position due to the characteristics of the waveform Leading Edge (representing uppermost canopy variability). Research presented by LEFSKY et al. (2005) succeeded in improving correlation with maximum field height when additionally incorporating the waveform Leading Edge parameter, increasing $\mathrm{R}^{2}$ from 0.59 to 0.69 and decreasing RMSE from 4.85 to $4.21 \mathrm{~m}$ for sites within the Great Smoky Mountains National Park, Tennessee, USA.

As part of this current study, the waveform leading edge and upper canopy variability were calculated to determine whether either may improve on the estimation of this 
maximum canopy height based on methods reported by LEFSKY et al. (2005). For the Forest of Dean, neither the uppermost height difference between Signal Begin and the first local waveform maximum, nor the upper canopy height variability between Signal Begin and the position of the maximum canopy peak resulted in statistically significant coefficients.

Therefore results using equation 1, substituting Waveform Extent and Terrain Index values for each footprint, were subsequently taken to be the most robust maximum canopy height estimations $\left(\mathrm{R}_{\mathrm{wT}}\right)$ and are used in later methods of estimating stemwood volume and identifying waveform parameters.

\section{Waveform estimators of stemwood volume}

Several waveform parameters were explored as potential indicators of stemwood volume:

- Maximum canopy height

Use of maximum canopy height estimations ( $\left.\mathrm{R}_{w \mathrm{~T}}\right)$ described above were examined. The square of these values $\left(\mathrm{R}_{\mathrm{wr}}\right)^{2}$ were also considered as an improved relationship had been previously achieved by LEFSKY et al. (2005).

- Height of cumulative energy percentiles

The waveform estimate of maximum canopy height $\left(R_{w T}\right)$ was used to locate the portion of the waveform representing the vegetation return. Within this region of the waveform, percentiles of cumulative energy (adapted from HARDiNG et al., 2001) were calculated and the heights at which the $50^{\text {th }}, 75^{\text {th }}$, $80^{\text {th }}, 90^{\text {th }}$ and $95^{\text {th }}$ percentiles occurred were used to estimate stemwood volume.
- Dominant canopy height

The height above the ground surface to the canopy return peak was named the dominant canopy height and was calculated by multiple regression using the Terrain Index presented in "canopy height" section and the elevation difference between the Signal End position and the elevation of the canopy return peak.

\section{- Canopy waveform area}

An alternative means of attributing waveform structure to volume of intercepted vegetation was investigated using the area under the canopy return. This was achieved by removing the ground surface contribution from the waveform. Two methods were explored, the first of which used the location of the ground peak represented by either Gaussian Peak 1 or 2, whichever demonstrated greatest amplitude (ROSETTE et al. submitted). If the ground peak was allocated to Gaussian Peak 1 , the sum of the areas beneath Peaks 2-6 was assumed to represent canopy volume, whilst volume was estimated as the total area of Gaussian Peaks 3-6 if Peak 2 was designated the ground return (Fig. 2b). The second method calculated the area beneath the waveform between the alternate fit signal begin position to the upper limit of the Terrain Index elevation.

\section{RESULTS}

\section{Tallest Species Stemwood Volume Estimates}

Regression analysis was carried out using the parameters described in "Waveform estimators of stemwood volume" section with yield model stemwood volume estimates ("single species stand volume" section). These results are shown in Table 1.

Table 1 Tallest species stemwood volume estimates

\begin{tabular}{|c|c|c|c|c|c|c|}
\hline Waveform parameter & Tallest species & $\mathrm{R}^{2}$ & Intercept & Coefficient & RMSE $\left(m^{3} / \mathrm{ha}\right)$ & Number \\
\hline \multirow{3}{*}{ Maximum canopy height $\left(\mathrm{R}_{\mathrm{wT}}\right)$} & Coniferous & 0.68 & NS & 13.8 & 88.7 & 55 \\
\hline & Broadleaf & 0.65 & NS & 8.27 & 68.2 & 18 \\
\hline & Combined & 0.60 & NS & 12.8 & 98.7 & 69 \\
\hline \multirow{3}{*}{$\left(\mathrm{R}_{\mathrm{wr}}\right)^{2}$} & Coniferous & 0.63 & $\begin{array}{c}80.0 \\
p>0.001\end{array}$ & 0.39 & 96.0 & 55 \\
\hline & Broadleaf & 0.57 & NS & 0.31 & 80.0 & 18 \\
\hline & Combined & 0.55 & $\begin{array}{c}73.7 \\
p>0.001\end{array}$ & 0.37 & 104.4 & 69 \\
\hline \multirow{3}{*}{$\begin{array}{l}\text { Height of } 90^{\text {th }} \text { percentile } \\
\text { cumulative energy }\end{array}$} & Coniferous & 0.50 & NS & 17.4 & 105.3 & 52 \\
\hline & Broadleaf & 0.64 & NS & 10.5 & 71.0 & 16 \\
\hline & Combined & 0.46 & NS & 16.2 & 111.2 & 65 \\
\hline
\end{tabular}

Comparison of tallest species stemwood volume with estimation results using waveform parameters. Groups include common footprints classified as un-vegetated. The number of footprints used differs due to missing values, discrepancies between Waveform Extent and estimated maximum height or anomalies such as 'negative' energy within height bins. Coefficients and intercepts are statistically significant $(p<0.001)$ except where stated. NS indicates not significant.

\section{J. For. Plann. 13:205-214(2008)}






a) Regression using maximum canop height $R_{-}$WT



b) Regression using maximum canopy height $R_{-}$WT

Fig. 3 Relationship between Forestry Commission (FC) stemwood volume predictions and volume estimates using Maximum Canopy Height $\mathrm{R}_{\mathrm{WT}}$, for (a) coniferous species, RMSE $88.7 \mathrm{~m}^{3} /$ ha and (b) broadleaf species, RMSE $68.2 \mathrm{~m}^{3} / \mathrm{ha}$.



a)

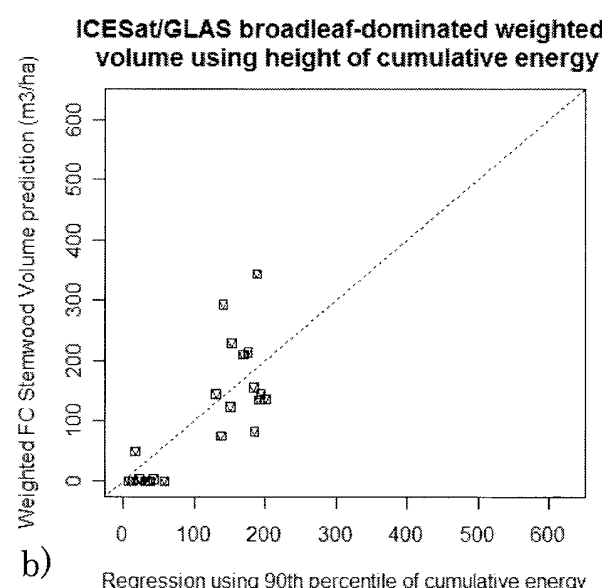

b) Regression using 90th percentile of cumulative energy

Fig. 4 Relationship between weighted stemwood volume predictions and volume estimates using height of the $90^{\text {th }}$ percentile of cumulative energy for footprints with greatest percentage cover by: (a) coniferous species, RMSE $92.3 \mathrm{~m}^{3} /$ ha and (b) broadleaf species, RMSE $67.5 \mathrm{~m}^{3} /$ ha. Please refer to Table 2 .

Table 3 Additional correlation ranges

\begin{tabular}{ccc}
\hline Waveform parameter & $\mathrm{R}^{2}$ range & RMSE range $^{3} / \mathrm{ha}$ \\
\hline $\begin{array}{c}\text { Dominant canopy height } \\
\text { Waveform canopy area } \\
\text { (Gaussian peaks) }\end{array}$ & $0.05-0.34$ & $100.2-143.4$ \\
& $0.08-0.19$ & $98.9-149.7$
\end{tabular}

Waveform canopy area $0.05-0.24$ (to upper terrain index limit)

Parameters shown were not found to be statistically significant or produced weak correlations. Ranges stated are for both stemwood volume methods.
Estimated maximum canopy height $\left(\mathrm{R}_{\mathrm{wT}}\right)$ produced the best estimate of stemwood volume for the tallest species within footprints with $\mathrm{R}^{2}$ of 0.60 and RMSE of $98.7 \mathrm{~m}^{3} / \mathrm{ha}$.

Differentiating between broadleaf and coniferous species improved the correlation to $\mathrm{R}^{2}$ of 0.65 , RMSE of $68.2 \mathrm{~m}^{3} /$ ha and $\mathrm{R}^{2}$ of 0.68 , RMSE of $88.7 \mathrm{~m}^{3} /$ ha respectively. These relationships are illustrated in Fig. 3.

Neither heights of cumulative energy percentiles nor the square of maximum canopy height improved these stemwood volume estimates. Other waveform parameters used did not produce statistically significant results or showed weak correlations (Table 3). 
Table 2 Mixed stand stemwood volume estimates

\begin{tabular}{|c|c|c|c|c|c|c|}
\hline Waveform parameter & Predominant species & $\mathrm{R}^{2}$ & Intercept & Coefficient & RMSE $\left(\mathrm{m}^{3} / \mathrm{ha}\right)$ & Number \\
\hline \multirow{3}{*}{ Maximum canopy height $\left(\mathrm{R}_{\mathrm{wT}}\right)$} & Coniferous & 0.52 & NS & 9.83 & 98.1 & 58 \\
\hline & Broadleaf & 0.48 & NS & 5.69 & 74.7 & 24 \\
\hline & Combined & 0.40 & NS & 8.90 & 105.9 & 69 \\
\hline \multirow{3}{*}{$\left(\mathrm{R}_{\mathrm{wT}}\right)^{2}$} & Coniferous & 0.50 & NS & 0.36 & 101.2 & 58 \\
\hline & Broadleaf & 0.45 & NS & 0.21 & 76.8 & 24 \\
\hline & Combined & 0.37 & $\begin{array}{c}46.0 \\
p>0.05\end{array}$ & 0.26 & 108.8 & 69 \\
\hline \multirow{3}{*}{$\begin{array}{l}\text { Height of } 90^{\text {th }} \text { percentile } \\
\text { cumulative energy }\end{array}$} & Coniferous & 0.57 & NS & 12.8 & 92.3 & 55 \\
\hline & Broadleaf & 0.59 & NS & 8.69 & 67.5 & 21 \\
\hline & Combined & 0.49 & NS & 11.9 & 94.9 & 65 \\
\hline
\end{tabular}

Comparison of weighted stemwood volume calculations with waveform parameter estimations. Groups include common footprints classified as un-vegetated and those with no dominant vegetation type. The number of footprints used differs due to missing values, discrepancies between Waveform Extent and estimated maximum height or anomalies such as 'negative' energy within height bins. Coefficients and intercepts are statistically significant $(\mathrm{p}<0.001)$ except where stated. NS indicates not significant.

\section{Mixed Stand Stemwood Volume Estimation}

Using the same waveform parameters, regression analysis was repeated for the mixed stand weighted stemwood volume estimates ("Mixed stand stemwood volume" section). Correlation was found to be lower for estimates of mixed stand stemwood volume than for the single species estimates discussed in "Tallest species stemwood volume estimates" section.

The height of the $90^{\text {th }}$ percentile of cumulative energy produced the best relationship with $\mathrm{R}^{2}$ of 0.49 , RMSE $94.9 \mathrm{~m}^{3} /$ ha for all footprints sampled.

Footprints were then distinguished according to whether the predominant vegetation cover consisted of broadleaf or coniferous species. This produced respectively $\mathrm{R}^{2}$ of 0.59 , RMSE $67.5 \mathrm{~m}^{3} /$ ha for broadleaf species and $\mathrm{R}^{2}$ of 0.57 , RMSE $92.3 \mathrm{~m}^{3} /$ ha for conifers. These relationships are shown in Fig. 4 whilst the results of all waveform parameter analyses are outlined in Tables 2 and 3.

\section{DISCUSSION}

A number of waveform-derived parameters were considered with respect to their ability to estimate stand stemwood volume as defined by independent estimates derived from yield models.

Previous work (ROSETTE et al. in press) has shown the ability for maximum canopy height to be extracted from GLAS waveforms over this study site. This enabled an assessment to be made of stemwood volume estimates for the corresponding tallest tree species within footprints.

Maximum canopy height is, by its nature, determined by little foliage of one or few trees within the stand. Therefore positions within and characteristics of the waveform canopy return were explored as, particularly for mixed stands, they are anticipated to better represent the combined contribution of the canopy elements for the diverse species present within footprints.

However, in some cases little relationship is seen which may be a result of these factors varying considerably between species e.g. the elevation of greatest returns from within the canopy is determined by species canopy structure which will also affect laser penetration. The validity of the methods using waveform canopy area are dependent on the degree to which reflectance between species differs at the measured wavelength $(1,064 \mathrm{~nm})$ in addition to the effects of canopy profile on multiple scattering events and their representation within waveforms. The weak correlation with weighted stemwood volume suggests that, for such highly mixed stands, if a relationship does exist with area under the waveform or dominant canopy height, the broad distinction between broadleaf and coniferous coverage is insufficient or that values are inconsistent due to variation in species structure or reflectivity. However, the highest correlation for mixed stand stemwood volume estimates was provided by relative positions within the canopy return produced using percentiles of cumulative energy.

Forestry sub-compartments that were listed by the Forestry Commission but classified as unpopulated (i.e. zero anticipated stemwood volume) were included in comparisons and the incorporation of these lower values has resulted in improved correlation.

Due to expected deviation in relationships between coniferous and broadleaf species, these groups were first analysed together as a sample forest population before being considered in isolation. NELSON et al. (2004) found estimates of 
volume and biomass using their Portable Airborne Laser System (PALS) to be significantly more accurate for conifers than for their hardwood grouping (i.e. deciduous trees). This paper shows only minor differences in correlation between coniferous and broadleaf species, whilst RMSE is seen to be lower for broadleaf-dominated footprints. However, mean values of stemwood volume for vegetated stands are $327.7 \mathrm{~m}^{3} /$ ha and $174.7 \mathrm{~m}^{3} /$ ha for coniferous and broadleaf species respectively and therefore a lower RMSE would be anticipated for the latter as a result of this alone. The results of this study suggest that differentiation may be necessary between coniferous and broadleaf species in order to use generalised relationships for broader scale stemwood volume estimates.

Dispersion among smaller volume values is observed and may be attributable to unmanaged re-growth or the effect of the 5 ns emitted pulse width producing an artificial minimum elevation difference of $1.5 \mathrm{~m}$ even for flat surfaces. An initial investigation suggests that, in most cases, GLAS waveforms are representing actual above surface features such as individual trees, shrubs or buildings.

Several waveform-based parameters within this study use the maximum canopy height estimated from the multiple regression equation using Waveform Extent and a Terrain Index with field measurements taken within 19 footprints. These estimates are dependent on the accuracy of the field measurements (LARSEN et al. 1987) in addition to how representative the selected footprints are of the complete pass. Future work will explore methods of estimating stemwood volume solely from waveform parameters.

Deviations from actual stand volumes are anticipated due to errors inherent in yield model predictions as individual stands may not perform in accordance with the models. If stand performance and management treatments differ from the yield model assigned, long-term forecast production for an individual stand may vary from actual production by $20 \%$ (EDWARDS and CHRISTIE, 1981). However, the sub-compartment database is updated annually to contain details of current conditions. Recent work conducted by the Forestry Commission at a stand level using yield model estimates calibrated with field measurements, produced vegetation height accuracy of $98 \%$ whilst, in the course of this study, a comparison of greatest field height measurements within 21 footprints with corresponding yield model estimates of Top Height for the tallest species revealed $\mathrm{R}^{2}$ of 0.94 .

Since top height is used within yield models they may be anticipated to provide a reasonable indication of the vegetation present. However sources of error are known and for coniferous stands, yield models have been found to overestimate actual volume. Furthermore, the Forestry Commission yield models are not dynamic and therefore do not account for mortality or species competition, assuming that stand composition remains that of the time of planting.

A further simplification made in this study is that the weighted stemwood volume calculation for mixed stands assumes a regular distribution of components within subcompartments. Nevertheless, these yield models offer the best available estimate of current conditions, are widely used in forest management and provide useful data in order to explore GLAS volume estimates.

LiDAR stemwood volume estimates with accuracy in excess of $60-70 \%$ are anticipated to be welcomed by forestry practitioners to contribute to national inventory. The results of this study suggest that for homogeneous sites, this can be achieved; however to reach this threshold for areas with more complex species composition would require greater refinement.

It is recognised that differences in relationships between maximum canopy height or percentiles of cumulative energy and stemwood volume within both coniferous species and broadleaf species groups are likely to contribute to a proportion of the variation observed. Investigation of a more homogenous site may reveal improved correlation and a possible significant contribution of other waveform parameters. Future work will also explore exploitation of the full waveform signal through radiative transfer modelling (NORTH 1996).

\section{CONCLUSION}

For a highly diverse, temperate forest, waveform-based calculations from maximum height estimations using ICESat/GLAS Waveform Extent and Terrain Index were compared with yield model estimates of stemwood volume. The results succeeded in estimating stemwood volume of the tallest species within coniferous stands with $\mathrm{R}^{2}$ of 0.68 and RMSE of $88.7 \mathrm{~m}^{3} /$ ha whilst for broadleaf stands, $\mathrm{R}^{2}$ of 0.65 and RMSE of $68.2 \mathrm{~m}^{3} /$ ha were produced.

An analysis of stemwood volume accounting for the mixed composition of stands contained within footprint areas was additionally carried out. A distinction was drawn between footprints dominated by coniferous or broadleaf species. Relationships using height of the $90^{\text {th }}$ percentile of cumulative energy explained $57 \%$ of variance, RMSE $92.3 \mathrm{~m}^{3} / \mathrm{ha}$, for footprints in which coniferous species are prevalent. Footprints with greatest cover formed by broadleaf species were found to produce $\mathrm{R}^{2}$ of 0.59 and RMSE of $67.5 \mathrm{~m}^{3} /$ ha.

The results suggest the potential for satellite LiDAR estimates of volume to be extended to regional and national scales and that a similar broad distinction between broadleaf or coniferous species may be sufficient to quantify vegetation for the requirements of forest inventory.

\section{ACKNOWLEDGEMENTS}

This research is funded by the UK Natural Environment Research Council (NERC), forming part of the objectives of the Climate and Land-Surface Systems Interaction Centre 


\section{(CLASSIC).}

Recognition is given to the Forestry Commission GB for their assistance with this work; in particular to Peter Burnett, staff at the Forest of Dean District Office and Genevieve Patenaude. Thanks are given to Sietse Los and Mike Barnsley of Swansea University plus Heiko Balzter, University of Leicester. Speakers at Silvilaser 2006 are also acknowledged for the insight into their related work, amongst whom are Michael Lefsky, Ross Nelson, Sorin Popescu, Guoquing Sun and Hayato Tsuzuki. Thanks are also due to the anonymous reviewer for the helpful comments and advice.

\section{LITERATURE CITED}

Abshire, J., Sun, X., Riris, H., Sirota, J., McGarry, J., Palm, S., Yi, D. and Liva, P., (2005): Geoscience Laser Altimeter System (GLAS) on the ICESat Mission: On-orbit measurement performance. Geophysical Research Letters 32: L21S02

BalzTER, H., Rowland, C.S. and Saich, P., (2007): Forest canopy height and carbon estimation at Monks Wood National Nature Reserve, UK, using dual-wavelength SAR interferometry. Remote Sensing of Environment 108: 224-239

Balzter, H., Skinner, L., Luckman, A. J. and Brooke, R., (2003): Estimation of tree growth in a conifer plantation over nineteen years from multi-satellite L-band SAR. Remote Sensing of Environment 84: 184-191

Brenner, A., Zwally, H., Bentley, C., Csathò, B., Harding, B., Hofton, M., Minster, J.-B., Roberts, L., SABa, J., Thomas, R. and YI, D., (2003): Derivation of Range and Range Distributions From Laser Pulse Waveform Analysis for Surface Elevations, Roughness, Slope, and Vegetation Heights. Algorithm Theoretical Basis Document V4.1. Available online at: http://www.csr.utexas. edu/glas/pdf/Atbd_20031224.pdf (accessed March 2005)

Bufton, J., (1989): Laser Altimetry Measurements from Aircraft and Spacecraft. Proceedings of the IEEE 77: 463-477

DeFries, R. S. and Townshend, J. R. G., (1994): NDVI-derived land cover classifications at a global scale. International Journal of Remote Sensing 15(17): 3567-3586

Drake, J. B., Dubayah, R. O., Clark, D. B., Knox, R. G., Blair, J. B., Hofton, M. A., Chazdon, R. L., Weishampel, J. F. and Prince, S. D., (2002): Estimation of tropical forest structural characteristics using large-footprint LiDAR. Remote Sensing of Environment 79: 305-319

Drake, J. B., Knox, R. G., Dubayah, R. O., Clark, D. B., Condit, R., BlaiR, J. B. and Hofton, M. A., (2003): Above-ground biomass estimation in closed canopy Neotropical forests using LiDAR remote sensing: factors affecting the generality of relationships. Global Ecology and Biogeography 12: 147-159

Edwards, P. N. and Christie, J. M., (1981): Yield Models for Forest Management, Booklet 48. Edinburgh, The Forestry Commission

Fang, J.-Y., Wang, G. G., Liu, G.-H. and Xu, S.-L., (1998): Forest Biomass of China: An estimate based on the Biomass - Volume Relationship. Ecological Applications 8(4): 1084-1091

FOREST RESEARCH, (2006): UK Forest Carbon Inventory. Available online at: http://www.forestresearch.gov.uk/website/forestresearch. nsf/By Unique/INFD-62XH5R (accessed June 2006)
Forestry Commission, (2006): Operational Guidance Booklet Number 6, Survey Handbook. Edinburgh, The Forestry Commission

Gardner, C., (1992): Ranging Performance of Satellite Laser Altimeters. IEEE Transactions on Geoscience and Remote Sensing 30: 1061-1072

Gaveau, D. L. A., Balzter, H. and Plummer, S., (2003): Forest woody biomass classification with satellite-based radar coherence over $900000 \mathrm{~km}^{2}$ in Central Siberia. Forest Ecology and Management, 174: $65-74$

Harding, D., Bufton, J. and Frawley, J., (1994): Satellite Laser Altimetry of Terrestrial Topography: Vertical Accuracy as a Function of Surface Slope, Roughness and Cloud Cover. IEEE Transactions on Geoscience and Remote Sensing 32: 329-339

Harding, D. and CARABajal, C., (2005): ICESat waveform measurements of within-footprint topographic relief and vegetation vertical structure. Geophysical Research Letters 32: L21S10

Harding, D. J., Blair, J. B., Rabine, D. R. and Still, K., (1998): SLICER: Scanning LiDAR Imager of Canopies by Echo Recovery. Instrument and Product Description

Harding, D. J., Lefsky, M. A., Parker, G. G. and Blair, J. B., (2001): Laser altimeter canopy height profiles; Methods and validation for closed-canopy, broadleaf forests. Remote Sensing of Environment 76: $283-297$

Hese, S., Lucht, W., Schmuluus, C., Barnsley, M., Dubayah, R., Knorr, D., Neumann, K., Riedel, T. and Schroter, K. (2005): Global biomass mapping for an improved understanding of the $\mathrm{CO}_{2}$ balance - the Earth observation mission Carbon-3D. Remote Sensing of Environment 94: 94-104

HiLl, R. A. and Thomson, A. G., (2005): Mapping woodland species composition and structure using airborne spectral and LIDAR data. International Journal of Remote Sensing 26(17): 3763-3779

Hyyppä, J., Kelle, O., Lehikoinen, M. and Inkinen, M., (2001): A Segmentation-based Method to Retrieve Stem Volume Estimates from 3-D Tree Height Models Produced by Laser Scanners. IEEE Transactions on Geoscience and Remote Sensing 39(5): 969-975

Jenkins, J., Chojnacky, D., Heath, L. and Birdsey, R., (2003): NationalScale Biomass Estimators for United States Tree Species. Forest Science 49(1): 12-35

KıCHAK, R., (2003), Chairman's Executive Summary, Technical Report. Independent GLAS Anomaly Review Board, Available online at: http://icesat.gsfc.nasa.gov/docs/IGARB.pdf (accessed June 2005)

Kotchenova, S., Shabanov, N., Knyazikhin, Y., Davis, A., Dubayah, R. and MYNENI, R., (2003): Modeling LiDAR waveforms with timedependent stochastic radiative transfer theory for remote estimations of forest structure. Journal of Geophysical Research 108, ACL 12: 1-13

Larsen, D., Hann, D. and Stearns-Smith, S., (1987): Accuracy and Precision of the Tangent Method of Measuring Tree Height. Western Journal of Applied Forestry 2(1): 26-28

Lefsky, M., Harding, D., Keller, M., Cohen, W., Carabajal, C., Del bom Espirito-Santo, F., Hunter, M., de Oliveira Jr., R. and DE CAmargo, P., (2005): Estimates of forest canopy height and aboveground biomass using ICESat. Geophysical Research Letters 32: L22S02

Lefsky, M. A., Harding, D., Cohen, W. B., Parker, G. and Shugart, H. 
H., (1999a): Surface LiDAR Remote Sensing of Basal Area and Biomass in Deciduous Forests of Eastern Maryland, USA. Remote Sensing of Environment 67: 83-98

Lefsky, M. A., Cohen, W. B., Acker, S. A., PARker, G. G., Spies, T. A. and HARDING, D., (1999b): LiDAR Remote Sensing of the Canopy Structure and Biophysical Properties of Douglas-Fir Western Hemlock Forests. Remote Sensing of Environment 70: 339-361

Los, S. O., Collatz, G. J., Sellers, P. J., Malmström, C. M., Pollack, N. H., DeFries, R. S., Bounoua, L., Parris, M. T., Tucker, C. J. and Dazlich, D. A., (2000): A Global 9-yr Biophysical Land Surface Dataset from NOAA AVHRR Data. Journal of Hydrometeorology 1(2): $183-199$

Los, S. O., Justice, C. O. and Tucker, C. J., (1994): A global $1^{\circ}$ by $1^{\circ}$ data set for climate studies derived from the GIMMS continential NDVI data. International Journal of Remote Sensing 15(17): 34933518

MAGIC, (2007): GIS Digital Boundary Datasets Forestry Commission Woodland. Available online at: http://www.magic.gov.uk/ staticmaps/national.htm (accessed January 2007)

Myneni, R. B., Hoffman, S., Knyazikhin, Y., Privette, J.L., Giassy, J., Tian, Y., Wang, Y., Song, X., Zhang, Y., Smith, G. R., Lotsch, A., Friedl, M., Morisette, J.T., Votavo, P., Nemani, R. R. and Running, S. W., (2002): Global products of vegetation leaf area and fraction absorbed PAR from year one MODIS data. Remote Sensing of Environment 83: 214-231

NÆsSET, E., (2002): Predicting forest stand characteristics with airborne scanning laser using a practical two-stage procedure and field data. Remote Sensing of Environment 80: 88-99

Nelson, R., Nesset, E., Gobakken, T., Ståhl, G. and Gregoire, T., (2006): Regional forest inventory using an airborne profiling LiDAR. Proceedings of the International Conference Silvilaser 2006, 7th-10th November 2006, Matsuyama, Japan

Nelson, R., Short, A. and Valenti, M., (2004): Measuring Biomass and Carbon in Delaware Using an Airborne Profiling LIDAR. Scandinavian Journal of Forest Research 19: 500-511

Ni-Meister, W., Jupp, D. L. B. and Dubayah, R., (2001): Modeling LiDAR Waveforms in Heterogeneous and Discrete Canopies. IEEE Transactions on Geoscience and Remote Sensing 39: 19431958

NoRTH, P. R. J., (1996): Three-dimensional forest light interaction model using a Monte Carlo method. IEEE Transactions on Geoscience and Remote Sensing 34(4): 946-956

North, P. R. J., (2002): Estimation of fAPAR, LAI and vegetation fractional cover from ATSR-2 imagery. Remote Sensing of Environment 80: 114-121

NSIDC, (2006): The Attributes for ICESat Laser Operations Periods. Available online at: http://nsidc.org/data/icesat/data.html (ac- cessed June 2006)

Ordnance SuRvey, (2006): OS Land-Form PROFILE DTM 1:10000 and 1: 25,000 Colour Raster (C) Crown Copyright/database right 2006. An Ordnance Survey/EDINA supplied service

Patenaude, G., Hill, R., Milne, R., Gaveau, D., Briggs, B. and DAwson, T., (2004): Quantifying forest above ground carbon content using LiDAR remote sensing. Remote Sensing of Environment 93: 368-380

Rosette, J., North, P. and SuÁrez, J., (in press): Vegetation Height Estimates for a Mixed Temperate Forest using Satellite Laser Altimetry. International Journal of Remote Sensing, 3D Forestry Special Issue

ROYAl FOREST OF DEAN, (2006): History. Available online at: http://www.visitforestofdean.co.uk/history.htm (accessed February 2006)

Schutz B., Zwally, H., Shuman, C., Hancock, D. and DiMarzio, J., (2005): Overview of the ICESat Mission. Geophysical Research Letters 32: L21S01

Sellers, P. J., Tucker, C. J., Collatz, G. J., Los, S. O., Justice, C. O., Dazlich, D. A. and Randall, D. A., (1994): A global 1 degree by 1 degree NDVI data set for climate studies. Part 2: The generation of global fields of terrestrial biophysical parameters from the NDVI. International Journal of Remote Sensing 15(17): 3519-3545

Suárez, J., Ontiveros, C., Smith, S. and Snape, S., (2005): Use of airborne LiDAR and aerial photography in the estimation of individual tree heights in forestry. Computers and Geosciences 31: 253-262

Tansey, K.J., Luckman, A.J., Skinner, L., Balzter, H., Strozzi, T. and WAGNER, W., (2004): Classification of forest volume resources using ERS tandem coherence and JERS backscatter data. International Journal of Remote Sensing 25: 751-786

UNFCCC, (2007): Kyoto Protocol. Available online at: http://unfccc.int/ kyoto_protocol/items/2830.php (accessed April 2007)

Zwally, H., Schutz, B., Abdalati, W., Abshire, J., Bentley, C., Brenner, A., Bufton, J., Dezio, J., Hancock, D., Harding, D., Herring, T., Minster, B., Quinn, K., Palm, S., Spinhirne J. and THomas, R., (2002): ICESat's Laser Measurements of Polar Ice, Atmosphere, Ocean and Land. Journal of Geodynamics 34: 405445

Zwally, H.J., Schutz, R., Bentley, C., Bufton, J., Herring, T., Minster, J., Spinhirne, J. and Thomas., R. (2006): GLAS/ICESat L1A Global Altimetry Data and L2 Global Elevation Data and Global Land Surface Altimetry data V026. Boulder, CO: National Snow and Ice Data Center. Digital media.

(Received 13 January 2007) (Accepted 3 August 2007) 